\title{
Amadeus
}

International Multidisciplinary Journal IISSN 2525-8281

V.2, N. 4. Jul./2018 - 10.14295/aimj.v2i4.34. ISSN 2525-8281

\section{THE IMMUNOMODULATORY ROLE OF VITAMIN D IN SYSTEMIC LUPUS ERYTHEMATOSUS: AN INTEGRATING LITERATURE REVIEW}

Lucas Tavares Cruz de Albuquerque ${ }^{1}$, Caroline Pereira Modesto ${ }^{2}$, Pedro de Sousa Leite ${ }^{3}$, Ana Aurélia Tavares da Cruz ${ }^{4}$, Djailson Ricardo Malheiro 5
Abstract: Vitamin D, conceptually, is a pre-hormone. Many studies have shown that the vitamin D deficiency may be associated to a higher incidence of autoimmune diseases, including Systemic Lupus Erythematosus. So, this work's purpose is identify what the scientific literature approaches about the vitamin D, highlighting its immunomodulatory role with the Systemic Lupus Erythematosus. We used the article survey that ran upon the subject in the Medline, Scielo and Lilacs databases with the descriptors: vitamin D, Systemic Lupus Erythematosus and autoimmune disease. The selected articles pointed out higher prevalence in the vitamin D deficiency and insufficiency in Lupus patients. In these, the supplementation appeared to improve the disease activity and inflammatory markers and shows a tendency for subsequent clinical improvement. However, there is a lack of adequate intake guidelines. In this way, researches about the best dosage of vitamin $\mathrm{D}$ are needed for these patients in order to improve their condition.

Keywords: Vitamin D. Systemic Lupus Erythematosus. Autoimmune disease.

\footnotetext{
${ }^{1}$ Medical student at the Medical School Estácio of Juazeiro do Norte (FMJ), Ceará, Brazil. Contact: lucastavares47@gmail.com

${ }^{2}$ Medical student at the Medical School Estácio of Juazeiro do Norte (FMJ), Ceará, Brazil.

Contact: carolinepmodesto@gmail.com

${ }^{3}$ Medical student at the Medical School Estácio of Juazeiro do Norte (FMJ), Ceará, Brazil.
}

Contact: pedroed1913@hotmail.com

${ }^{4}$ Master's degree in Regional Development by the Regional University of Cariri (URCA), Juazeiro do Norte, Ceará, Brazil. Contact: anaaureliat@yahoo.com.br

${ }^{5}$ Master's degree in Geography by the State University of Ceará (UECE). Assistent Professor at the Medical School Estácio of Juazeiro do Norte (FMJ), Ceará, Brazil. Contact: djailsonricardo@gmail.com 


\section{Introduction}

Vitamin D, when we talk about concept, it's a pre-hormone, despite being called vitamin (Maeda et al., 2014). To the vitamin D is mainly attributed to the important function of regulating osteomineral physiology, especially calcium metabolism. However, this compound participates in the homeostasis of several other cellular processes such as the synthesis of natural antibiotics by defense cells, synthesis of inflammatory interleukins, autoimmunity modulation, blood pressure control and participates in regulation of the processes of cell multiplication and differentiation, so, it's also attributed the role of anthocyanogenic (Castro, 2011). Vitamin D has more than 900 potential target-genes that correspond to $3 \%$ of the human genome, so, many of its actions in the human body have not been discovered yet (Eserian, 2013).

The main source of vitamin D is represented by endogenous formation in the epidermis spinous layer after exposure to ultraviolet-B (UV-B) radiation through sunlight. An alternative source is diet and corresponds to only $20 \%$ of the body's need for vitamin D (Oliveira et al., 2014).

The two main forms of vitamin D are vitamin D2 (ergocalciferol) and vitamin D3 (cholecalciferol). However, vitamin D3 is the only one found naturally in humans and other animals (Ding et al., 2012). In the epidermis, when exposed to UV-B radiation, the 7dehydrocholesterol - vitamin D precursor -, is converted to pre-vitamin D3. This molecule, on a break for 48 hours, undergoes a heat-dependent molecular rearrangement, resulting in cholecalciferol. To avoid vitamin D overproduction after prolonged solar exposures, the previtamin D3 can be metabolized in two biologically inert compounds: lumisterol and tachysterol (Marques et al., 2010).

To exert influence on mineral metabolism and other physiological functions, it's indispensable that vitamin $\mathrm{D}$ be converted into its active hormone. In this way, the cholecalciferol is transported in the blood by the vitamin D-Binding Protein (DBP) to the liver. In this organ, vitamin D undergoes hydroxylation, catalyzed by one or more cytochrome P450 enzymes, resulting in 25-hydroxyvitamin D (25 (OH) D), this one being the main storage form of vitamin D. In the proximal contorted tubule cells of the kidney, $25(\mathrm{OH}) \mathrm{D}$ is 
metabolized by the enzyme 1- $\alpha$-hydroxylase to 1,25 -dihydroxyvitamin $\mathrm{D}\left(1,25(\mathrm{OH})_{2} \mathrm{D}_{3}\right)$ or calcitriol, its biologically active form (Inda; Melamed, 2013).

The biological actions of the active form of vitamin D are mediated through the vitamin D receptor (VDR), a transcription factor that belongs to the nuclear receptor family, which regulates the DNA transcription into RNA. The $1,25(\mathrm{OH})_{2} \mathrm{D}_{3}$ binds to the VDR leading to conformational change and formation of the transcription hormone-receptor complex, which is associated too one of the retinoid $X$ receptors (RXR), the nuclear receptor for retinoic acid, forming heterodimers that act on a DNA sequence in the target genes, called vitamin D response element (VDRE). After the dimerization with the RXR, the heterodimer recruits complexes of co-modulators proteins that induce the genes activation or repression (Abbas, 2017). Therefore, the 1,25-dihydroxyvitamin D modulates the transcription of specific genes.

The change in gene expression involves several cellular functions, including: proliferation, differentiation, apoptosis and angiogenesis. Vitamin D directly influences $\mathrm{T}$ and $\mathrm{B}$ lymphocytes, improving the $\mathrm{T}$ cell proliferation induced by the $\mathrm{T}$-cell receptor and promotes the synthesis of regulatory $\mathrm{T}$ cells (Treg), as well as decreases the differentiation of B cells and inhibits the production and secretion of autoantibodies. It's also known that the vitamin $\mathrm{D}$ active form inhibits the secretion of interferon- $\gamma(I F N-\gamma)$ and interleukin 12 (IL-12) by dendritic cells. Vitamin D stimulates the differentiation of monocytes into macrophages and regulates the production and secretion of inflammatory cytokines by macrophages (Bae; Lee, 2018).

Currently, data link vitamin D deficiency to many autoimmune diseases (Mohammed et al., 2016), which are characterized by the loss of immune homeostasis, resulting in autoantigens recognition followed by the body tissue destruction by immune cells. A combination of genetic, epidemiological and environmental factors contributes to the development of autoimmune diseases. An importante factor may be represented by insufficient levels of vitamin D, since several epidemiological studies suggest an association between vitamin $\mathrm{D}$ deficiency and a higher incidence of autoimmune diseases, incluiding Systemic Lupus Erythematosus (SLE) (Prietl et al., 2013).

SLE is a chronic inflammatory disease of autoimmune origin because it presents itself by the production of several autoantibodies due to an immune system dysfunction, affecting 
several organs and systems (Souza et al., 2014). Besides that, SLE reaches mainly childbearing age women, with a proportion of approximately 9:1 between women and men (Marinho; Taveira; Vasconcelos, 2017).

Several pathophysiological mechanisms were identified in patients with SLE, including aberrant apoptosis and defective depuration of apoptotic materials, such as nuclear autoantigens and immunocomplexes by macrophages and complement system; increased maturation of myeloid dendritic cells that stimulate T cell development in Th17 cells; and defective function of Treg cells, leading to hyperactivity of Th cells and activation of autoreactive B cells that produce autoantibodies (Mok, 2013).

So, this work's objective is to identify what the scientific literature approaches about vitamin D, highlighting its immunomodulatory role with the Systemic Lupus Erythematosus (SLE).

\section{Method}

It's an literature integrative review that covered the following steps: guiding question definition; establishment of the review objectives; criterion demarcation for inclusion and exclusion of articles; informations definition to be extracted from the selected articles; results analysis; discussion and presentation of the obtained data.

In this way, the following databases were consulted: Medical Literature Analysis and Retrieval System Online (Medline), Scientific Electronic Library Online (Scielo), Latin American and Caribbean Literature in Health Sciences (Lilacs), using the descriptors: vitamin D, Systemic Lupus Erythematosus and autoimmune disease, in english, from April to June 2018. The selected articles followed the following inclusion criterion: a) studies written in English and Portuguese in the last nine years; b) original articles and reviews; c) articles with full text available online.

Thesis, monographs and unpublished works were excluded from the study. We adopted a form to collect data from the selected articles, obtaining information about the author, publication date, objectives and research main conclusions. 


\section{Results}

The searches carried out totaled, initially, 76 articles. After the analysis of the inclusion criterion, ten articles were selected constituting the final sample. Table 1 presents a general summary of the articles included in the final sample, in addition to the authors, publication year, objectives and main conclusions.

Table 1 - Authors, objectives and main conclusions of the selected articles.

\begin{tabular}{|c|c|c|}
\hline Authors & Objectives & Main conclusions \\
\hline Abaza, N. M. et al., 2016. & $\begin{array}{l}\text { Estimate the prevalence of vitamin D } \\
\text { deficiency in SLE patients and its } \\
\text { relation to the disease. }\end{array}$ & $\begin{array}{c}\text { The prevalence of vitamin D } \\
\text { insufficiency and deficiency was } \\
\text { detected in } 73,3 \% \text { and } 23,3 \% \text {, } \\
\text { respectively. Vitamin D had a } \\
\text { negative correlation with the disease } \\
\text { activity index. }\end{array}$ \\
\hline $\begin{array}{l}\text { Abou-Raya, A.; Abou-Raya, S.; } \\
\text { Helmii, M., } 2012 .\end{array}$ & $\begin{array}{l}\text { Evaluate the vitamin D status in SLE } \\
\text { patients, the determined changes in } \\
\text { the inflammatory and hemostatic } \\
\text { markers and the disease activity } \\
\text { before and after vitamin D } \\
\text { supplementation. }\end{array}$ & $\begin{array}{l}\text { Supplementation increased serum } \\
\text { vitamin D levels, improved } \\
\text { inflammatory and hemostatic } \\
\text { markers, and decreased disease } \\
\text { activity. Vitamin D appears to play } \\
\text { an immuno-inflammatory- } \\
\text { modulatory role that may benefit } \\
\text { SLE musculoskeletal and } \\
\text { cardiovascular manifestations. }\end{array}$ \\
\hline Dankers, W. et al., 2017. & $\begin{array}{l}\text { Provide an overview of the clinical } \\
\text { trials that were conducted on vitamin } \\
\text { D and autoimmune diseases. }\end{array}$ & $\begin{array}{c}\text { In SLE patients, supplementation } \\
\text { with } 2.000 \text { IU per day or } 50.000 \mathrm{IU} \\
\text { weekly showed a decrease in disease } \\
\text { activity score, autoantibody levels } \\
\text { and fatigue. }\end{array}$ \\
\hline Eloi, M. et al., 2017. & $\begin{array}{l}\text { Evaluate the prevalence of vitamin D } \\
\text { deficiency in SLE patients and } \\
\text { investigate the association between } \\
\text { total, free and bioavailable serum } \\
\text { concentrations and disease activity. }\end{array}$ & $\begin{array}{l}\text { A high frequency of vitamin D } \\
\text { deficiency and insufficiency was } \\
\text { demonstrated among SLE patients. } \\
\text { Disease activity was associated with } \\
\text { 25(OH)D low serum concentrations. } \\
\text { Measurements of vitamin D-binding } \\
\text { protein with monoclonal ELISA and } \\
\text { calculations of free and bioavailable } \\
\text { vitamin D didn't differ between } \\
\text { disease activity categories. }\end{array}$ \\
\hline Kamen, D. L., 2009. & $\begin{array}{l}\text { Describe the prevalence of vitamin D } \\
\text { deficiency in SLE patients, identify } \\
\text { the risk factors for disability, } \\
\text { describe the consequences of the } \\
\text { deficiency and review vitamin N } \\
\text { current recommendations for patients } \\
\text { with SLE and other rheumatic } \\
\text { diseases. }\end{array}$ & $\begin{array}{l}\text { They believe that vitamin D may be } \\
\text { effective as a suppressive } \\
\text { intervention for SLE patients. } \\
\text { Patients will also avoid morbidity } \\
\text { and mortality excess associated with } \\
\text { vitamin D deficiency. }\end{array}$ \\
\hline Mok, C. C., 2013. & $\begin{array}{l}\text { Correlate vitamin D low levels with } \\
\text { the SLE activity and evolution and }\end{array}$ & $\begin{array}{l}\text { Vitamin D low levels have been } \\
\text { associated with atherosclerotic risk }\end{array}$ \\
\hline
\end{tabular}




\begin{tabular}{|c|c|c|}
\hline & other diseases. & $\begin{array}{l}\text { factors in patients with Lupus. } \\
\text { Patients with vitamin D deficiency } \\
\text { demonstrated lower bone mineral } \\
\text { density of the lower femoral neck } \\
\text { compared to those with } \\
\text { insufficiency. After vitamin D } \\
\text { supplementation, it was noted a } \\
\text { decrease in Th1 and Th17 effector } \\
\text { cells, B cells and anti-DNA } \\
\text { antibodies. }\end{array}$ \\
\hline Ritterhouse, L. L. et al., 2011. & $\begin{array}{c}\text { Explore the impact of low vitamin D } \\
\text { levels on autoantibody production in } \\
\text { healthy individuals, as well as B cell } \\
\text { hyperactivity and interferon } \alpha(\text { IFN } \alpha) \\
\text { activity. }\end{array}$ & $\begin{array}{l}\text { Vitamin D deficiency is associated } \\
\text { with the elevated blood levels of } \\
\text { IFN- } \alpha \text { and increased B-cell } \\
\text { activation, which may lead to an } \\
\text { exaggerated rate of autoantibody } \\
\text { production directed against nucleic } \\
\text { acids in a patient with SLE. }\end{array}$ \\
\hline Souza, V. A. et al, 2014. & $\begin{array}{l}\text { Evaluate the association between } \\
\text { vitamin D insufficiency with SLE } \\
\text { and inflammatory markers. }\end{array}$ & $\begin{array}{l}\text { Vitamin D insufficiency was more } \\
\text { prevalent in SLE patients and it was } \\
\text { associated with higher levels of IL- } 6 \\
\text { and hematúria presence. }\end{array}$ \\
\hline Sumethkul, K. et al., 2012. & $\begin{array}{l}\text { Define serum levels of } 25(\mathrm{OH}) \mathrm{D} \\
\text { among patients with inactive SLE, } \\
\text { active SLE without Lupus Nephritis } \\
\text { and active SLE with Lupus Nephritis } \\
\text { and identify the clinical predictor of } \\
\text { vitamin D deficiency. }\end{array}$ & $\begin{array}{l}\text { SLE patients with Lupus Nephritis } \\
\text { have more vitamin D lower levels } \\
\text { than inactive SLE and active SLE } \\
\text { without Lupus Nephritis. Therefore, } \\
\text { nephritis is a disability predictor in } \\
\text { SLE patients. }\end{array}$ \\
\hline Yap, K. S.; Morand, E. F., 2014. & $\begin{array}{l}\text { Define the potential relationship } \\
\text { between vitamin D status and SLE, } \\
\text { in addition to clarifying the role of } \\
\text { vitamin } D \text { tests and replacement } \\
\text { therapy in the course of the disease. }\end{array}$ & $\begin{array}{l}\text { Vitamin D supplementation induced } \\
\text { an increase in CD } 4^{+} \mathrm{T} \text { virgin cells } \\
\text { and Treg cells and a decrease in } \\
\text { memory Th1, Th17 cells, memory B } \\
\text { cells and anti-DNA antibodies. As a } \\
\text { treatment for vitamin D deficiency is } \\
\text { recommended a daily dose of } 3.000- \\
5.000 \text { IU for } 6 \text { to } 12 \text { weeks followed } \\
\text { by } 1.000-2.000 \text { IU maintenance per } \\
\text { day. }\end{array}$ \\
\hline
\end{tabular}

Source: Elaborated by the authors (2018).

\section{Discussion}

SLE patients are more likely to develop hypovitaminosis D due to several factors. In the first place, SLE patients are photosensitive from what the exposure to UVB rays can trigger or either by systemic SLE crisis. As a result, these patients are advised to avoid exposure to sunlight and apply sunscreen during outdoor activities (Yap; Morand, 2014).

Second, SLE patients usually have renal impairment and the vitamin D hydroxylation in its active form may be discontinued in renal disease. A study, carried out in Thailand, 
analyzed the relationship between plasma vitamin D in Lupus Nephritis (NL) patients: 108 patients were divided into three groups that consisted of active SLE with NL, active SLE without NL and inactive SLE. The authors found out that patients with SLE and NL had vitamin Dlower levels than in the other two groups, suggesting that nephritis predisposes vitamin D deficiency (Sumethkul et al., 2012).

Third, drugs used to treat Lupus may decrease serum vitamin D levels. Corticosteroids chronic use reduces intestinal absorption and accelerates the degradation of 25hydroxyvitamin $\mathrm{D}$ and 1,25-dihydroxyvitamin $\mathrm{D}$ by increasing the action of the 24- $\alpha$ hydroxylase enzyme (Kamen, 2009). Patients that take glucocorticoids may need higher doses of vitamin D supplementation to maintain adequate serum levels. Besides, patients may also use hydroxychloroquine in their therapeutic project. There are suspicions that this substance will prevent the conversion of $25(\mathrm{OH}) \mathrm{D}$ to $1,25(\mathrm{OH})_{2} \mathrm{D}_{3}$ (Yap; Morand, 2014).

A number of evidence lines suggest that vitamin D has an inhibitory action in many of the abnormalities associated with SLE. Vitamin D may be related to downregulation of the Th1 immune response and activated B-cells proliferation and to the upregulation of Treg cells. In SLE patients, calcitriol inhibited dendritic cells maturation and expression of interferon- $\alpha$ (IFN- $\alpha)$-induced genes. In a more recent study, in which one 20 SLE patients who had vitamin $\mathrm{D}$ deficiency were supplemented with vitamin $\mathrm{D}$, it was shown that vitamin $\mathrm{D}$ refilling induced an increase in virally $\mathrm{CD}^{+} \mathrm{T}$ virgin cells and Treg cells and a decrease in Th1 cells, Th17, B memory cells and anti-DNA antibodies (Yap; Morand, 2014).

Ritterhouse et al. (2011) found out that vitamin D deficiency $(<20 \mathrm{ng} / \mathrm{ml})$ is associated to the increased serum IFN- $\alpha$ and increased B-cells activation which may contribute to increased production of autoantibodies directed against nucleic acids in SLE patients.

Vitamin D, as a steroidal hormone, has several functions in different systems, exerting these functions through its VDR receptor, which is widely distributed in the body, mainly in the immune system (Fragoso et al., 2012). In the SLE, VDR undergoes polymorphism by altering its functionality and influencing autoimmunity regulation. The VDR receptor gene, when it suffers the various types of polymorphisms, may play a risk role for SLE. According to a recent meta-analysis based on previous conclusions, the Bsmll B allele of VDR may be a 
risk factor for the disease onset in the general population, while in Asians the Fokl FF genotype presentes as a risk factor for the disease onset (Yap; Morand, 2014).

SLE patients are more likely to have atherosclerosis at an early age and have a higher standardized incidence rate for arterial thrombosis compared to the general population. Vitamin D low levels were associated with certain atherosclerotic risk factors in patients with Lupus (Mok, 2013). Wu et al. (2009) studied 181 SLE patients and demonstrated that low serum vitamin D levels were associated to the diastolic blood pressure, LDL cholesterol, and body mass index (BMI).

Vitamin D deficiency also presents an increased osteoporosis risk for SLE patients. Low serum vitamin D levels decrease intestinal calcium absorption and induce bone demineralization. A longitudinal study examined 38 SLE patients and found that those with vitamin D deficiency $(<20 \mathrm{ng} / \mathrm{mL})$ demonstrated lower bone mineral density of the lower femoral neck compared to those with vitamin D insufficiency (21-30ng $/ \mathrm{mL})$. After two years of vitamin D supplementation, there was a tendency to increase the mineral density in those who were initially insufficient compared to those who were deficient (Mok, 2013).

Often, SLE patients have fatigue higher levels - more than $50 \%$ of patients present as their most disabling symptom (Yap; Morand, 2014). Ruiz-Irastorza et al. (2010) carried out a study with 80 SLE patients and demonstrated a negative correlation between $25(\mathrm{OH}) \mathrm{D}$ levels and the visual analogue scale (VAS) that measures fatigue.

Abaza et al. (2016), in their studies to estimate the prevalence of vitamin D deficiency in SLE patients and their relationship with the disease, observed serum concentrations of $25(\mathrm{OH}) \mathrm{D}$ in $60 \mathrm{SLE}$ patients and 30 healthy patients from the group control. Significantly lower levels were found in SLE patients $(6,9-17,6 \mathrm{ng} / \mathrm{mL})$ in relation to the control group $(28,7-79,0 \mathrm{ng} / \mathrm{mL})$. The prevalence of vitamin D insufficiency and deficiency was detected in $73,3 \%$ and $23,3 \%$, respectively. Vitamin D had a negative correlation with the Systemic Lupus Erythematosus Disease Activity Index (SLEDAI), Systemic Lupus International Collaborating Clinics (SLICC) and fatigue.

In the research carried out by Eloi et al. (2017) aimed to evaluate the prevalence of vitamin D in SLE patients and investigate the association between total, free and bioavailable concentration of vitamin D and disease activity. A total of 142 patients $(71,4 \%)$ had plasma levels of $25(\mathrm{OH}) \mathrm{D}$ below $30 \mathrm{ng} / \mathrm{ml}$. The total serum concentration of $25(\mathrm{OH}) \mathrm{D}$ is associated to 
the disease activity categorized by the five SLEDAI groups. The 25 -hydroxyvitamin D concentration was higher among patients with SLEDAI 1-5 and lower in those with severe disease activity (SLEDAI $\geq 20$ ). However, no significant difference was observed for vitamin D-binding protein (DBP), free and bioavailable vitamin D.

In a cross-sectional study carried out by Souza et al. (2014), 45 SLE patients and 24 healthy patients without the disease were reunited to evaluate the association between vitamin D insufficiency, SLE and inflammation. It was noted that, in Lupus patients, vitamin D insufficiency was prevalent in $55 \%$ of the cases and it's associated to the interleukin 6 (IL-6) higher levels when compared to the group of SLE patients with vitamin D sufficiency and the group without the disease.

Vitamin supplementation in SLE may be more relevant than other autoimmune diseases, since $80 \%$ of patients are photosensitive. Two studies with SLE patients, one with vitamin D supplementation of 2.000 IU per day and the other with the supplementation of 50.000 IU per week, demonstrated a decrease in disease activity, number of autoantibodies and fatigue. However, the Interferon type I concentration remained unchanged for 12 weeks (Dankers et al., 2017).

According to Abou-Raya, Abou-Raya and Helmi (2012), in a randomized study to evaluate the SLE activity before and after vitamin D supplementation and vitamin D role in inflammatory and hemostatic processes, it was concluded that this vitamin has a potential immunosuppressive and anti-inflammatory role and hypovitaminosis D contributes to chronic inflammation and the thrombolytic state. The authors found out that patients who received oral cholecalciferol supplementation at a dose of 2.000 IU per day for 12 months, compared to patients in the placebo group, had improved the disease activity and inflammatory markers (IL-1, IL- 6, IL-18 and TNF- $\alpha$ ) and hemostatics (fibrinogen, von Willebrand factor). In addition, the proportion of patients with insufficient vitamin D fell from $69 \%$ to $19 \%$ in the last month of the study.

In a prospective study, 20 SLE patients with mild to moderate disease activity and vitamin D insufficiency were supplemented with high doses in the form of cholecalciferol (100.000 IU per week for four weeks followed by 100.000 IU per month for six months). The plasma concentration of $25(\mathrm{OH}) \mathrm{D}$ increased at the end of the study. It was also observed, in 
$\mathrm{CD}^{+}$Treg cells and Treg, a preferential increase and a decrease in Th1 and Th17 effector cells, B cells and anti-DNA antibodies (Mok, 2013).

Nowadays, there are no guidelines on the vitamin D supplementation specific dosage to SLE patients. The American College of Rheumatology suggests a vitamin D intake of 800$1.000 \mathrm{IU}$ per day in patients with initial corticosteroid use. It was also noted that that corticosteroids may disrupt vitamin D absorption, so, vitamin D higher doses may be required to achieve adequate serum levels. Other factors can be considered, as well as: skin pigmentation, BMI, sun exposure and geographical location. An Australian position about vitamin D and bone health in the treatment of vitamin D deficiency is the daily dose of 3.0005.000 IU during six to twelve weeks followed by the maintenance of 1.000-2.000 IU per day (Yap; Morand, 2014).

Based on recent researches, SLE was the only disease in which there is a wide study about the supplementation impact on treatment. The results are promising, but further studies must be done before using vitamin D in these patients treatment (Dankers et al., 2017).

\section{Conclusion}

In the last years, it was given bigger attention to the non-calcemic functions of vitamin D. Evidences suggest that vitamin D may play an important role in regulating the immune system and preventing autoimmune diseases.

In Systemic Lupus Erythematosus (SLE), vitamin D may be related to the decreased proinflammatory defense cells, cytokines and autoantibodies. Hypovitaminosis D is commonly observed in Lupus patients due to several factors. Many studies have shown that low serum vitamin D levels are related to the disease activity increase, cardiovascular disease risk, osteoporosis and fatigue. Vitamin D supplementation in SLE patients appeared to improve the disease activity and inflammatory markers and show a tendency for subsequent clinical improvement. However, there are no adequate intake guidelines for SLE patients.

Therefore, further researches about the best dosage of vitamin D are needed for Lupus patients in order to improve their condition. 


\section{References}

Abaza, N. M. et al.(2016). Vitamin D Deficiency in Egyptian Systemic Lupus Erythematosus Patients: How Prevalent and Does It Impact Disease Activity?. Integrative Medicine Insights, (11), 27-33.

Abbas, M. A. (2017). Physiological functions of Vitamin D in adipose tissue. The Journal Of Steroid Biochemistry And Molecular Biology, (165), 369-381.

Abou-Raya, A.; Abou-Raya, S.; Helmii, M. (2013). The Effect of Vitamin D Supplementation on Inflammatory and Hemostatic Markers and Disease Activity in Patients with Systemic Lupus Erythematosus: A Randomized Placebo-controlled Trial. J Rheumatol, (40) 3, 265-272.

Bae, S; Lee, Y. H. (2018). Vitamin D level and risk of systemic lupus erythematosus and rheumatoid arthritis: a Mendelian randomization. Clinical Rheumatology, 1-7.

Castro, L. C. G. (2016). O sistema endocrinológico vitamina D. Arq Bras Endocrinol Metab, (55) $8,566-575$.

Dankers, W. et al. (2017). Vitamin D in Autoimmunity: Molecular Mechanisms and Therapeutic Potential. Frontiers In Immunology, (7)4, 1-26.

Ding, C. et al. (2015). Vitamin D signalling in adipose tissue. British Journal of Nutrition, (108)11, 1915-1923.

Eloi, M. et al. (2017). 25-Hydroxivitamin D Serum Concentration, Not Free and Bioavailable Vitamin D, Is Associated with Disease Activity in Systemic Lupus Erythematosus Patients. Plos One, (12)1, 1-10.

Eserian, J. K. (2013). Papel da vitamina D no estabelecimento e tratamento de transtornos neuropsiquiátricos. Rev. Ciênc. Méd. Biol, (12) 2, 234-238.

Fragoso, T. S. et al. (2012). Níveis séricos de 25-hidroxivitamina D3 e sua associação com parâmetros clínicos e laboratoriais em pacientes com lúpus eritematoso sistêmico. Revista Brasileira de Reumatologia, (52) 1, 60-65.

Inda, A. J., Fo; Melamed, M. L. (2013). Vitamina D e doença renal. O que nós sabemos e o que nós não sabemos. J Bras Nefrol, (35) 4,323-331.

Maeda, S. S. et al. (2014). Recomendações da Sociedade Brasileira de Endocrinologia e Metabologia (SBEM) para o diagnóstico e tratamento da hipovitaminose D. Arq Bras Endocrinol Metab, (58) 5, 411-433.

Marinho, A.; Taveira, M.; Vasconcelos, C. (2017). Topics on vitamin D in systemic lupus erythematosus: analysis of evidence and critical literature review. Immunologic Research,1-7. 
Marques, C. D. L. et al. (2010) A importância dos níveis de vitamina D nas doenças autoimunes. Rev Bras Reumatol, (50)1, 67-80.

Mohammed, H. A. et al. (2017). Immunomodulatory and Immunosuppressive Roles of $1 \alpha, 25(\mathrm{OH}) 2 \mathrm{D} 3$ in Autoimmune Diseases. Scandinavian Journal of Immunology, ( 85) 2,95103.

Mok, C. C. (2013). Vitamin D and systemic lupus erythematosus: an update. Expert Review of Clinical Immunology, ( 9) 5, 453-463.

Oliveira, V. et al. (2014). Influência da vitamina D na saúde humana. Acta Bioquím Clín Latinoam, (48)3, 339-347.

Prietl, B. et al. (2013). Vitamin D and Immune Function. Nutrients, ( 5)7, 2502-2521.

Ritterhouse, L. L. et al. (2011). Vitamin D deficiency is associated with an increased autoimmune response in healthy individuals and in patients with systemic lupus erythematosus. Annals of The Rheumatic Diseases, (70)9, 1569-1574.

Ruiz-Irastorza, G. et al. (2010). Changes in vitamin D levels in patients with systemic lupus erythematosus: Effects on fatigue, disease activity, and damage. Arthritis Care \& Research, (62) 8,1160-1165.

Souza, V. A. et al. (2014) Associação de hipovitaminose D com Lúpus Eritematoso Sistêmico e inflamação. J Bras Nefrol, (36)4,430-436.

Sumethkul, K. et al. (2012). The predictive factors of low serum 25-hydroxyvitamin D and vitamin D deficiency in patients with systemic lupus erythematosus. Rheumatology International, (33) 6, 1461-1467.

Wu, P. W. et al. (2009). 25-hydroxyvitamin D and cardiovascular risk factors in women with systemic lupus erythematosus. Arthritis \& Rheumatism, (61) 10,1387-1395.

Yap, K. S.; Morand, E. F. (2014). Vitamin D and systemic lupus erythematosus: continued evolution. International Journal of Rheumatic Diseases, (18) 2, 242-249.

\section{How to cite this article (APA format):}

Albuquerque, Lucas Tavares Cruz de; Modesto, Caroline Pereira; Leite, Pedro de Sousa; Cruz, Ana Aurélia Tavares da; Malheiro. The Immunomodulatory Role of Vitamin D in Systemic Lupus Erythematosus: an Integrating Literature Review. (2018). Hansen's Disease epidemiological profile characterization in Cajazeiras Region in the State of Paraíba. Am In. Mul J, 2 (4), p. 88-99.

Received: 07/04/2018.

Accepted: 2/06/2018. 